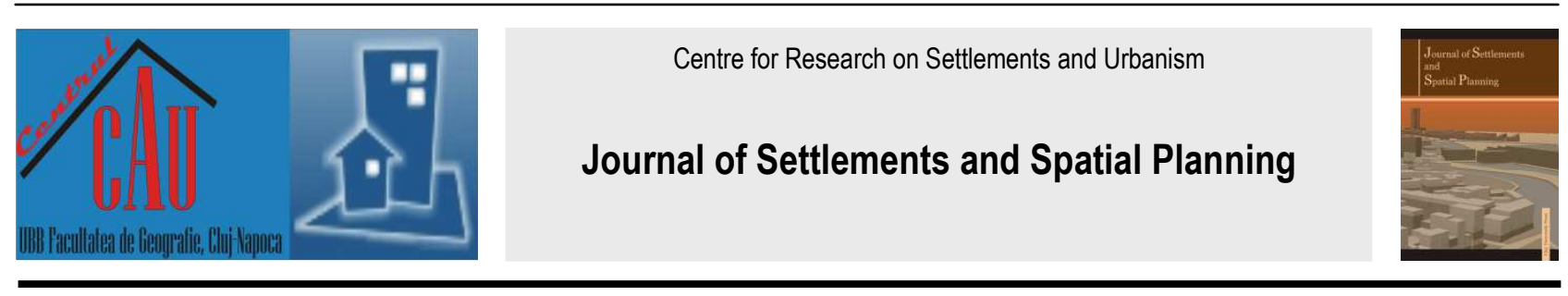

\title{
Analysing Urban Sprawl and Shifting of Urban Growth Centre of Bengaluru City, India Using Shannon's Entropy Method
}

\author{
Sarthak VERMA', Amit CHATTERJEE ${ }^{1}$, Nikhil Ranjan MANDAL ${ }^{1}$ \\ ${ }^{1}$ School of Planning and Architecture, Department of Planning, Bhopal, Madhya Pradesh, INDIA \\ E-mail: sarthakverma112@gmail.com, amit.chatterjee@spabhopal.ac.in,nrmandal@spabhopal@ac..in \\ DOI: 10.24193/JSSP.2017.2.02 \\ https://doi.org/10.24193/JSSP.2017.2.02
}

K e y w o r d s: Shannon's Entropy, urban growth, urban sprawl, Bengaluru, GIS

\begin{abstract}
A B S T RA C T
Urbanization is considered as a significant driver of land use and land cover change which is closely associated with the growth of population and economy. Geographical Information System and remote sensing technology are efficient tools for detecting patterns and trends of urban growth. In order to avoid unwanted impact of urban growth at the local and regional level, planning for expected future growth is essential. Bengaluru (previously known as Bangalore), in Karnataka, India, is a city of economic success, challenges, opportunities, hopes and above all, a city of dreams for immigrants. The study aims to quantify trends of urban growth in Bengaluru city using Geographical Information System, remote sensing techniques and Shannon's Entropy method. The study reveals an increasing trend in the entropy values for the city signifying urban sprawl or dispersed development of the city. It also indicates spatial shifting of growth centres within the city. Results of demographic and spatial analysis were verified through visual survey of ground truth. The process and the findings have a high utility to comprehend the land use changes and forecast expansion patterns to develop a future scenario, which may be further used to prepare planning and management strategies at regional as well as local levels.
\end{abstract}

\section{INTRODUCTION}

Developing nations have a higher rate of urbanization than the developed nations. As a result of accelerated economic development, the developing nations are facing the uncontrolled expansion of the urban centres ensuing dramatic landscape changes [1]. Unrestricted change in landscape escalates loss of green cover, fertile land, and environmental degradation. Urbanization is closely associated with the growth of population and is a significant driver of land use and land cover changes [2]. One of the key reasons for urbanization is industrialization, which leads to largescale urban expansion by encroaching on agricultural lands. Over-crowded cities with limited resources are compelling people to move out in the fringe areas, which in numerous ways, has adverse impacts on the environment. Urbanization is an inevitable process, but efforts can be made to influence and regulate the growth process using urban land use planning interventions to safeguard natural resources and meet demands of the city residents as well, to make the whole process sustainable. Hence, there is an increasing need for accurate mapping and monitoring of changes in the urban environment.

Urban India accommodated 377 million people (31.2\% of total population), the second largest urban population in the world as per Census 2011 [3]. According to United Nation's estimate in 2014, by the year 2050, half of India's populations are expected to live in urban areas [4]. Many Indian large cities, especially the large metropolises and metropolitan regions are facing challenges with respect to their growth, composition, spatial spread, congestion, 
environmental degradation, housing and infrastructure availability as well as accessibility. Bengaluru, the socalled 'Silicon valley of India' (previously: Bangalore), administered by Bruhat Bengaluru Mahanagara Palike (BBMP) is no exception to these trends. Ramachandra (2016) in his research named Bengaluru as 'Dead city', and its wild urbanization as 'senseless growth' [5]. This study attempts to analyze and decipher the patterns and trends of spatial growth process in Bengaluru city.

This paper is divided into four sections and following this section of introduction, section 2 presents theoretical aspects of Shannon's Entropy Method, methodology adopted for this study and a description of current growth, population concentration and land cover changes in Bengaluru city. Section 3 discusses the results of analysis and section 4 provides conclusions drawn from the research findings and the consequent policy implications.

\section{THEORY AND METHODOLOGY}

\subsection{Literature review}

Population growth is the key driver of urban sprawl, and spatial distribution of the population is concentrated around city centre, but randomly at suburban areas [6], [7]. This random spatial growth of built-up land (generally housing) refers to urban sprawl [8], [9], [10]. Accurate temporal information about the state of urbanization, the rate of urban expansion, the patterns and extent of sprawl is often not available in an adequate manner for a suitable analysis. However, this information is needed by spatial planners to plan for the services required to meet the needs of the urban population [11]. The concept of entropy was first introduced by Boltzmann and Gibbs in the year 1975 [12] and later, it was employed in mathematics and engineering through the efforts of Kolmogrov and Shannon in the year 2001 [13]. Entropy illustrates the extent of complexity in a system and it is zero for deterministic events. It has many interdisciplinary applications in different areas of science and engineering to characterize temporal behaviour of the complex dynamical systems [14], [15]. Entropy is well known as a measure of uncertainty or spread of random variables with many finite outcomes on a nominal scale [16].

To quantify urban expansion, different metrics are used in the literature. The Shannon's urban entropy measures the degree of spatial concentration and dispersal of built-up land between different time periods [17], [18], [19], [20]. It is an index which determines the distribution of built up land as a function of the total area of built up land within a defined spatial unit [21]. The entropy value reflects the dispersion or concentration of the spatial variable within a specified spatial unit, hence characterizing the built area patterns, which is used to differentiate types of sprawl [1]. Sudhira et al. (2004) used Shannon's entropy, patchiness and built-up density in conjunction with regression analysis to quantify and model the urban sprawl of Mangalore-Udupi region of India [9]. Kumar et al. (2007) used landscape metrics and Shannon's entropy to monitor the urban expansion of Indore and Ajmer cities respectively [22]. Taubenbock et al. (2009) used spatial metrics such as built-up density, landscape shape index, largest patch index, the number of patches, total edge and edge density to capture the spatio-temporal urban form of the 12 most populated Indian cities [11].

There is hardly any availability of scientific studies regarding the assessment of shifting of urban growth centres, as a result of which city managers and planners often fail to undertake timely and appropriate assessments on the conditions of urban sprawl development and its direction for preparing development plans of cities, particularly in developing nations. The Shannon's entropy is an evolving tool for monitoring the degree of spatial concentration and dispersal of built-up land for an urban area and therefore, a preliminary attempt has been made to assess the urban sprawl of Bengaluru city using this technique.

\subsection{Methodology}

Shannon's Entropy is calculated using the equation given by Yi and Li (2001), as shown below:

Shannon's Entropy $H_{n}=-\sum_{i=1}^{n} p_{i} \log _{e}\left(P_{i}\right)$

where:

$P i$ - is the probability of variable occurring in the $i^{\text {th }}$ zone $<$

$n$ - is the total number of zones [1].

The entropy values range from o to $\ln (n)$. The value of $\mathrm{o}$ indicates that the distribution is very compact or concentrated, whereas the values closer to $\ln (n)$ reveal dispersed distribution of the built-up area. Further, values can be normalized within a range for a better understanding of the obtained results. Landsat satellite imageries for Bengaluru city was acquired for aset of years and processed to classify the image into various land cover classes. Urban sprawl over a period of 1973 to 2016 was determined by computing urban area from the classified image. In this study, objectbased classification in an iterative manner has been carried out for extracting the built-up area pixels from the data set. The decadal difference between urban built-up areas was computed to determine the change in the built-up area. Buffer rings were created around the core city centre at intervals of $1 \mathrm{~km}$ from the centre up to $22 \mathrm{~km}$, which were further divided into 4 zones 


\section{Analysing Urban Sprawl and Shifting of Urban Growth Centre of Bengaluru City, India Using Shannon's Entropy Method \\ Journal of Settlements and Spatial Planning, vol. 8, no. 2 (2017) pp.}

namely, northeast, southeast, northwest and southwest, for identification of sprawl direction and growth in individual zones. Urban areas were extracted for each ring for comparative growth over a period of time for each ring. The Shannon's entropy value was calculated for all the 22 rings and for the four zones which were compared to observe the pattern of urban growth over several decades with respect to the distance from the city centre (Fig. 1).

Further, a visual survey was conducted to confirm the ground truth and verify the relationship between entropy value of different zones and growth of newly built-up areas within BBMP area.
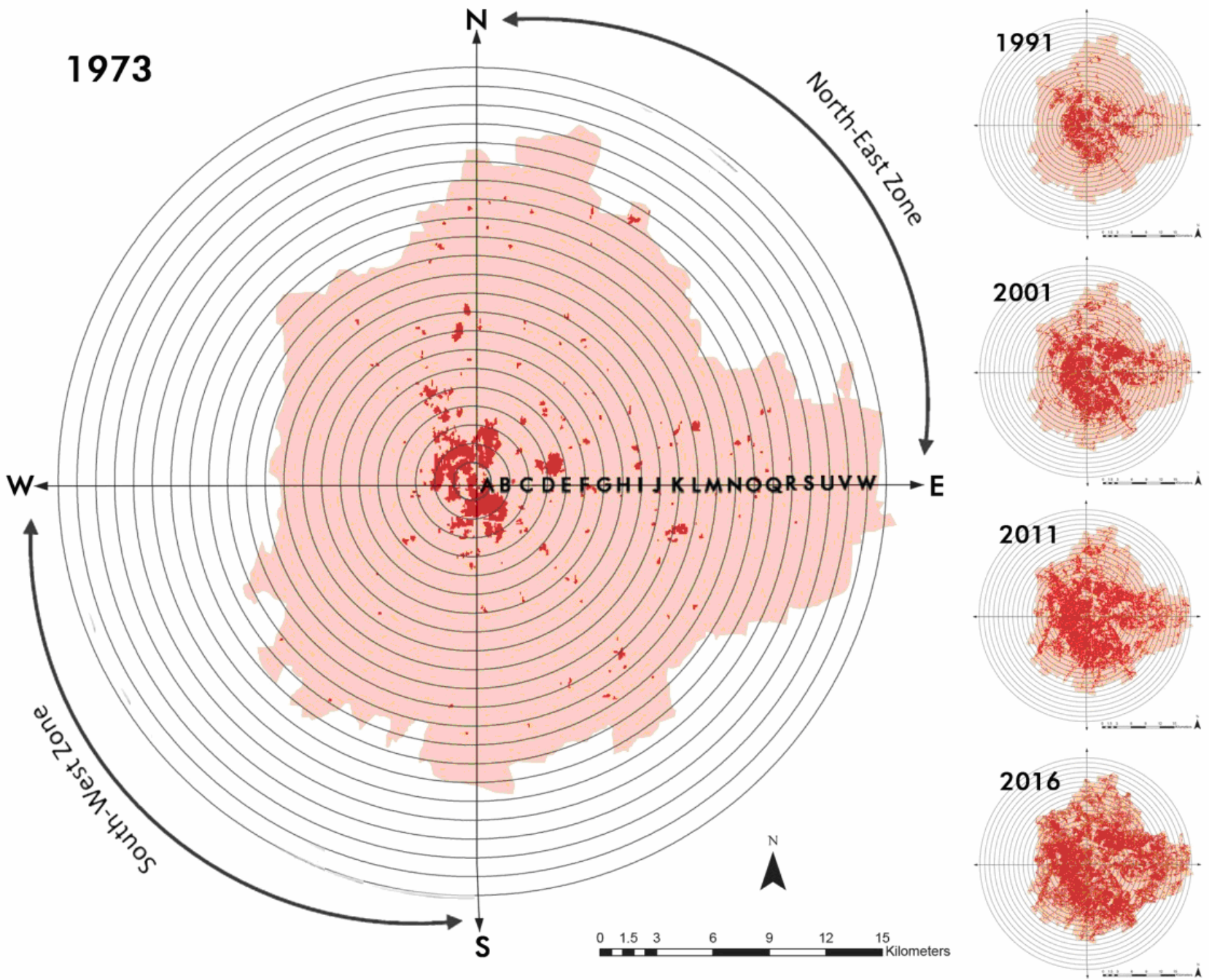

Fig. 1. Showing built-up areas, concentric rings and zones for entropy calculations.

\subsection{The case of Bengaluru}

Bengaluru is a rapidly developing city of southern India. Indian Census of 2011 has ranked it as the fifth largest urban agglomeration of India. It is located in Bangalore district of the Karnataka state. From Table 1, it is evident that, among the mega cities of India, Bengaluru has experienced the highest average annual growth rate of population $(4.73 \%)$ in the last decade (2001-2011) and has been in the top bracket of growth rate consistently in the last four decades. It may be presumed that the same trend may continue for the ongoing decade (2011-2021) as well.

It is seen from Figure 2 that since 1901 there has been a continuous growth of population in Bangalore city in absolute number till 2011. Bangalore grew at a high rate, and the population of Bangalore increased from 5.7 million to 8.4 million during the decade 2001-2011.

The growth of Bengaluru from a town to a metropolis has been a result of five growth events: i) shifting of the State Capital from Mysore after India's independence, ii) merging of the Cantonment with the city (1949), iii) setting up of Public Sector Undertakings/Academic Institutions (since 1970s), iv) development of Textile Industry (1911-1931), v) development of Information Technology/ITES/Biotech based industries (since 1980s). It is obvious that the population growth in Bengaluru is an obvious result of the continuous flow of immigrants from surrounding areas and other regions to Bengaluru. Nearly half (45\%) 
of the population had been categorized as immigrants in the 2001 Census [28]. Bengaluru covers $10 \%$ of geographical area and has a population share of almost $72 \%$ of Bengaluru Metropolitan Region (BMR).

According to 2011 census, the gross density of Bengaluru was of 6,645 persons per sq $\mathrm{km}$. High rate of population growth has put challenges of adequacy of infrastructure and land use conversion in the peripheral areas. Water supply, sewerage, and transportation are the key sectors under stress in Bengaluru city. Bengaluru incurs a huge economic loss due to traffic congestion. Only $40 \%$ of the city is under the coverage of sewerage system [29]. A recent comparative study of 25 cities in different parts of the world suggests that Bengaluru follows a high growth path that is quite different from cities in the USA, with urbanization being constrained in the core due to lack of space, but with rapid spatial expansion of urban areas in the city periphery [30].

Taubenböck et al. (2009) corroborated this in a study of multiple Indian cities, suggesting that Bengaluru is transitioning from a formerly mononucleated growth pattern to a polycentric pattern, with the fastest growth taking place around multiple peripheral areas. This pattern of growth, with the city core becoming increasingly saturated, and new urbanization centres developing at the periphery, can be traced to multiple factors. High land prices in the city centre and lack of large spaces for further urbanization have led to the location of many public sectors, local and multinational companies, and prominent educational institutions at the city periphery [31].

Table 1. Showing the Average Annual Growth Rate of mega cities.

\begin{tabular}{l|rrrrrr}
\multirow{2}{*}{ Cities (UA) } & \multicolumn{2}{|c}{ Population } & \multicolumn{4}{c}{ Average Annual Growth Rate of Population (\%) } \\
& (Million) $\mathbf{2 0 1 1}$ & $\mathbf{2 0 0 1 - 2 0 1 1}$ & $\mathbf{1 9 9 1 - 2 0 0 1}$ & $\mathbf{1 9 8 1 - 1 9 9 1}$ & $\mathbf{1 9 7 1 - 1 9 8 1}$ \\
\hline Greater Mumbai & 18.41 & 1.25 & 2.99 & 2.62 & 4.22 \\
Kolkata & 14.11 & 0.68 & 1.99 & 1.82 & 1.72 \\
Delhi & 16.19 & 2.66 & 5.19 & 4.18 & 3.8 \\
Chennai & 8.69 & 3.53 & 1.85 & 1.7 & 2.23 \\
Bangalore & 8.49 & 4.73 & 3.77 & 3.2 & 3.36 \\
Hyderabad & 7.74 & 4.01 & 2.74 & 2.42 & 5.2 \\
Ahmedabad & 6.35 & 4.06 & 3.64 & 3.11 & 2.58
\end{tabular}

Source: Calculated by authors from various census years [23], [24], [25], [26], [27].

As a result, loss of agricultural land, water body, and green spaces are faster in periphery areas of Bengaluru. It is imperative that urban planning efforts concentrate on the city periphery where unplanned growth is taking place at a rapid rate.

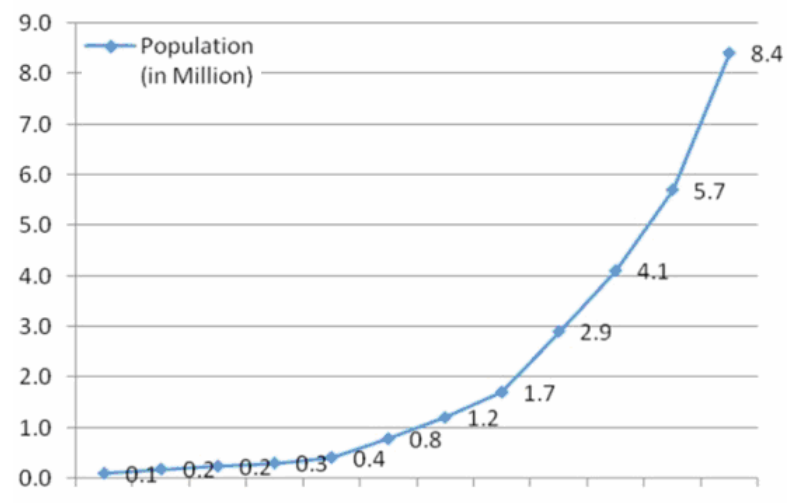

190119111921193119411951196119711981199120012011

Fig. 2. Population growth of Bengaluru city (19012011). Source: Census of India (1901-2011) [32].

\section{RESULTS AND DISCUSSION}

Spatial changes as land cover changes from 1973-2016 are indicated in Table 2. They represent urban growth pattern in terms of built up land for
Bengaluru city. A decrease in share covers the agriculture (pasture) land, land with dense vegetation (tree cover), wetland, and water bodies and an increase of built-up land and barren land were observed. Percentage of built-up land has been increasing at an alarming rate (from $2.53 \%$ in 1973 to $48.61 \%$ in 2016).

Accuracy assessment is an essential stage for map generation from any satellite image data. The accuracy assessment was carried out for the classification of the urban area and it was observed that overall accuracy levels of $83.61 \%, 85.48 \%, 86.62 \%$ and 89.14\% were achieved for the years 1991, 2001, 2011 and 2016 respectively, while the kappa coefficients were $0.82,0.83,0.84$ and 0.87 for the respective years. The minimum accuracy for a reliable land cover classification should be $85 \%$ [33].

Therefore, it has been assumed that the classification accuracy in the study is appropriate. Builtup area in 1991 was of $144.53 \mathrm{sq} \mathrm{km}$ and increased to $358.30 \mathrm{sq} \mathrm{km}$ by the year 2016. The urban area has grown approximately two and a half time in the last two decades. The settlement built-up pattern and new additions from the year 1973 to 1991 is shown in the Figure 3 followed by Table 3 showing estimations. Buffer rings were created at an interval of $1 \mathrm{~km}$ from the 
core city centre up to $22 \mathrm{~km}$, covering the entire Bengaluru municipal corporation area as shown in
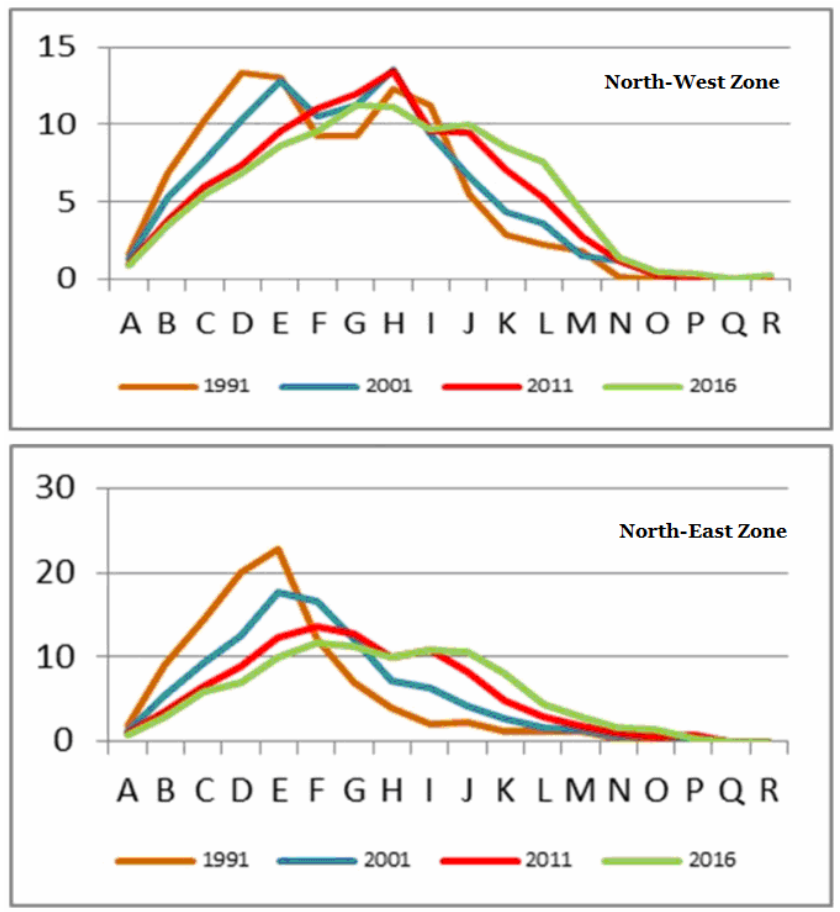

Figures 1 and 3 (with ring $\mathrm{A}$ in the centre to ring $\mathrm{V}$ at the periphery).
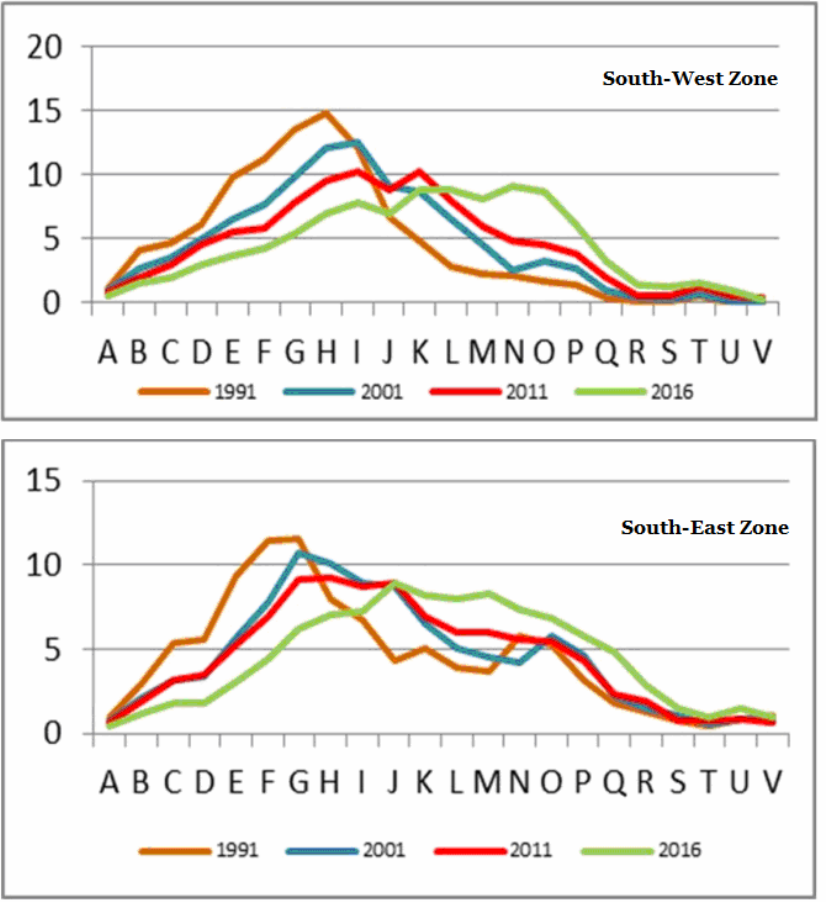

Fig. 3. Zone-wise distribution of built-up up area within each ring in Bengaluru city (\%).

Table 2. Land cover changes of the Bengaluru City (1973-2016).

\begin{tabular}{|c|c|c|c|c|c|c|}
\hline \multirow{2}{*}{ Land Cover } & \multicolumn{2}{|c|}{2016} & \multicolumn{4}{|c|}{ Year wise percentage land cover } \\
\hline & Area $\left(\mathbf{k m}^{2}\right)$ & $(\%)$ & 2011 & 2001 & 1991 & 1973 \\
\hline Barren Land & 109.77 & 14.92 & 10.67 & 4.83 & 7.17 & \\
\hline $\begin{array}{l}\text { Dense Vegetation } \\
\text { (Tree cover) }\end{array}$ & 59.04 & 8.07 & 13.36 & 21.66 & 23.38 & - \\
\hline Built up area & 358.3 & 48.61 & 38.73 & 28.96 & 19.61 & 2.53 \\
\hline Agriculture (Pasture Land) & 186.87 & 25.39 & 33.13 & 36.99 & 44.92 & - \\
\hline Water body & 10.38 & 1.23 & 1.35 & 1.53 & 1.73 & 2.12 \\
\hline Wetland / Healthy vegetation & 12.78 & 1.78 & 2.76 & 6.03 & 3.2 & - \\
\hline Total & 737.15 & 100 & 100 & 100 & 100 & \\
\hline
\end{tabular}

Table 3. Temporal change of built-up area of Bengaluru City (1973-2016).

\begin{tabular}{r|rrrrrr}
\multirow{2}{*}{ Year } & \multicolumn{9}{|c}{ Built-up (in sq km) } \\
& $\begin{array}{l}\text { North-East } \\
\text { zone (NE) }\end{array}$ & $\begin{array}{l}\text { North West } \\
\text { Zone (NW) }\end{array}$ & $\begin{array}{c}\text { South East } \\
\text { Zone } \\
\text { (SE) }\end{array}$ & $\begin{array}{l}\text { South West } \\
\text { Zone (SW) }\end{array}$ & $\begin{array}{c}\text { Population } \\
\text { (in millions)+ }\end{array}$ & $\begin{array}{c}\text { Bengaluru } \\
\text { City }\end{array}$ \\
\hline 1973 & 5.4 & 5.53 & 5.39 & 2.37 & $1.66^{*}$ & 18.68 \\
1981 & NA & NA & NA & NA & 2.92 & NA \\
1991 & 41.89 & 33.4 & 47.01 & 22.23 & 4.13 & 144.53 \\
2001 & 64.08 & 42.8 & 69.76 & 36.83 & 5.69 & 213.47 \\
2011 & 78.67 & 56.71 & 94.41 & 55.58 & 8.43 & 285.37 \\
2016 & 111.63 & 67.56 & 113.9 & 65.21 & NA & 358.3
\end{tabular}

Note: + Population from different census years, ${ }^{*}$ considering 1971 census year populationBuilt-up area calculated by authors from different years Landsat satellite imageries for Bengaluru city.

Further, Figure 6 shows the effect of distance from the city core on the entropy values. The entropy values may range between $\mathrm{o}$ and 1 where, the maximum value 1 represents distribution of built up land across 
the space and the minimum value $\mathrm{o}$ is concentration of built-up land in one area [34]. This will held true for cases when normalized values of built-up land is used for the calculations. In this study, ratio of built-up land in an individual ring to total built-up area available in all the rings have used for the value of 'Pi'. Hence, the entropy values ranges from zero to $\log _{\mathrm{e}}(\mathrm{n})$, (here $\mathrm{n}=22$ ) the value of $\log _{\mathrm{e}}(22)$, which is equals 3.05 .

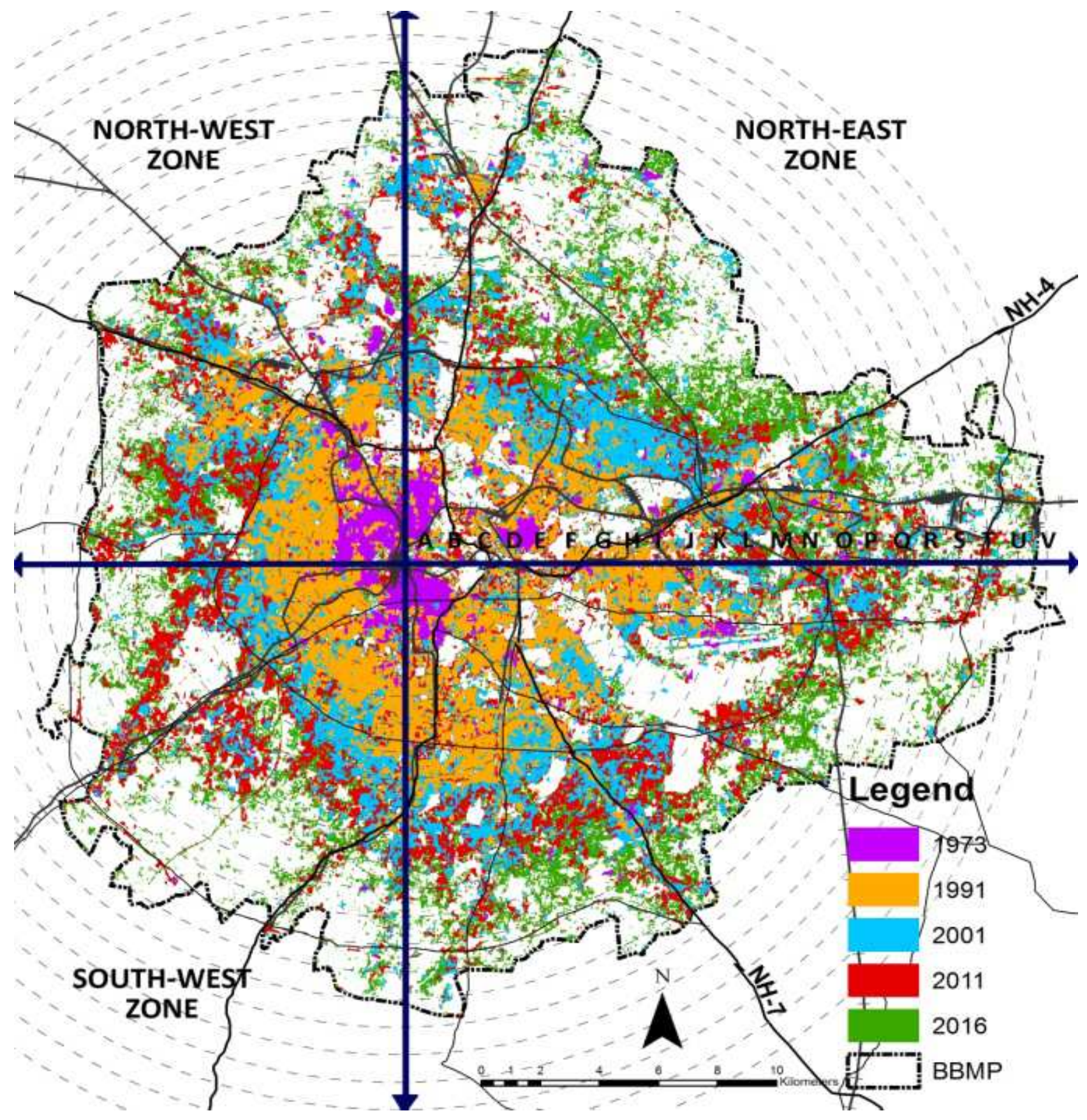

Fig. 4. Temporal change of built-up area of Bengaluru City (1973-2016).

Figure 4 (zone wise) and Figure 5 (overall BBMP area) indicated distribution of percentage of built-up area within each of the rings for the years 1991, 2001, 2011 and 2016.

In this study, entropy values for different years have been compared as represented in Figure 6. It has been argued that when the entropy value of any later year becomes more than that of the earlier years, greater dispersal of development is indicated. 94
Conversely, as long as the entropy values of any studied year remains less than that of the later years, it indicates compactness of development. Based on this argument, Figure 6 indicates that Bengaluru is a compact urban settlement within $11 \mathrm{~km}$ (till ring ' $\mathrm{K}$ ', wherein the year-wise line pattern reverses the respective positions) from the city core and beyond it becomes dispersed. It has been observed that compactness of development in 2001 was up to $8 \mathrm{~km}$ 


\section{Analysing Urban Sprawl and Shifting of Urban Growth Centre of Bengaluru City, India Using Shannon's Entropy Method \\ Journal of Settlements and Spatial Planning, vol. 8, no. 2 (2017) pp.}

(i.e. H Ring) from the city core (entropy values of year 1991 became more than that of 2001 beyond this ring), which increased by $1 \mathrm{~km}$ in 2011 (I ring) and in 2016 it has further increased up to $11 \mathrm{~km}$ (i.e. K Ring) (using similar argument). The entropy values after $\mathrm{K}$ ring was high in the year 2016 as compared to 2011 and the previous years due to new development in the peripheral area. Also, as the city expanded, residential buildings located in the city core were prone to get redeveloped or converted to commercial use, as a result of which people residing in the city centre migrated to outer rings of the city which was the additional reason of an increase in entropy values.

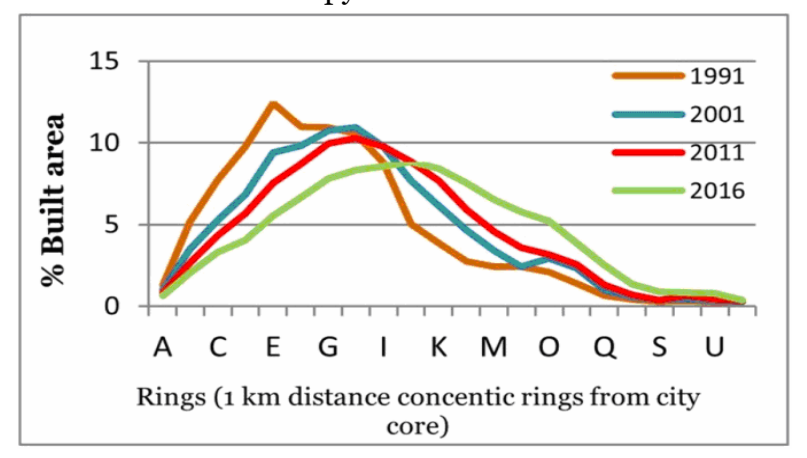

Fig. 5. Distribution of built-up area within each ring in Bengaluru city (\%).

Built-up area and entropy values of overall BBMP area from 1973 to 2016 are shown in Table 4 and built-up area while the entropy values of each zone of BBMP area are revealed in Table 5 .

The built-up area and entropy values for the year 2016 in South-East and North-East zones were higher as compared to North-West and South-West zones, indicating that the city grew in east direction with high sprawling characteristics.

Table 4. Showing the entropy values for entire Bengaluru City.

\begin{tabular}{l|rrr} 
Year & \multicolumn{3}{|c}{ Overall BBMP Area } \\
& $\begin{array}{c}\text { Population } \\
\text { (in million) }\end{array}$ & $\begin{array}{c}\text { Built-up (sq } \\
\text { km) }\end{array}$ & $\begin{array}{c}\text { Entropy } \\
\text { value } \\
\text { (Overall city) }\end{array}$ \\
\hline 1973 & $1.66^{*}$ & 18.68 & 1.8 \\
1981 & 2.92 & NA & NA \\
1991 & 4.13 & 144.53 & 2.58 \\
2001 & 5.69 & 213.47 & 2.66 \\
2011 & 8.43 & 285.37 & 2.7 \\
2016 & NA & 358.3 & 2.77 \\
considering 1971 census year population. & different census years, *
\end{tabular}

This happened due to the presence of IT hub "Whitefield" in eastern parts of Bengaluru, inducing the development activities. The built-up area has been observed to be growing along the major highways, viz. Chennai highway ( $\mathrm{NH} 7$ ) and Hyderabad highway $(\mathrm{NH}$ 4) (Fig. 4).

The built-up area has increased in the southeast direction rapidly from 2011 to 2016 due to the discontinued commercial usage of the HAL airport in 2008 and removal of many construction restrictions in the 'air funnel' allowing for more constructions. On comparing the development pattern, the west direction developed in more compact fashion as compared to east. In the east due to the presence of natural features like lakes, forest area, and eco-sensitive areas, the development is more sprawling in nature.

Table 5. Showing the Entropy values in each zone of Bengaluru city.

\begin{tabular}{|c|c|c|c|c|c|c|c|c|}
\hline \multirow{3}{*}{ Year } & \multicolumn{2}{|c|}{ North-East Zone } & \multicolumn{2}{|c|}{ North-West Zone } & \multicolumn{2}{|c|}{ South-East Zone } & \multicolumn{2}{|c|}{ South-West Zone } \\
\hline & \multirow{2}{*}{$\begin{array}{l}\text { Built-up } \\
\text { (sq km) }\end{array}$} & \multirow{2}{*}{$\begin{array}{c}\text { Entropy } \\
\text { value }\end{array}$} & \multirow{2}{*}{$\begin{array}{l}\text { Built-up } \\
\text { (sq km) }\end{array}$} & \multirow{2}{*}{$\begin{array}{c}\text { Entropy } \\
\text { value }\end{array}$} & \multirow{2}{*}{$\begin{array}{l}\text { Built-up } \\
\text { (sq km) }\end{array}$} & \multirow{2}{*}{$\begin{array}{c}\text { Entropy } \\
\text { value }\end{array}$} & \multirow{2}{*}{$\begin{array}{c}\text { Built-up } \\
\text { (sq km) }\end{array}$} & \multirow{2}{*}{$\begin{array}{c}\text { Entropy } \\
\text { value }\end{array}$} \\
\hline & & & & & & & & \\
\hline 1973 & 5.4 & 1.75 & 5.53 & 1.88 & 5.39 & 2.15 & 2.37 & 1.37 \\
\hline 1981 & \multicolumn{8}{|c|}{ NA } \\
\hline 1991 & 41.89 & 2.76 & 33.4 & 2.34 & 47.01 & 2.49 & 22.23 & 2.12 \\
\hline 2001 & 64.08 & 2.77 & 42.8 & 2.4 & 69.76 & 2.62 & 36.83 & 2.3 \\
\hline 2011 & 78.67 & 2.79 & 56.71 & 2.43 & 94.41 & 2.72 & 55.58 & 2.41 \\
\hline 2016 & 111.63 & 2.79 & 67.56 & 2.49 & 113.9 & 2.76 & 65.21 & 2.47 \\
\hline
\end{tabular}

A visual survey was conducted to confirm the ground truth and verify relationship between entropy value of different zones and growth of newly built areas within BBMP area. The visual survey confirmed shifting of urban growth centre towards a south-east direction, a conclusion which could be derived based on the frequency of the newly constructed structures. The population of Bengaluru has increased by an average annual growth rate of $4.73 \%$ in the last decade 20012011. Primarily, the population growth has taken place in the peri-urban areas of Bengaluru city, especially in the south-east zone and north-east zone, as presented in the Table 3 .

During last decade, entropy values have remained almost constant in the north-east zone, whereas in southeast zone high change was observed. 
This zone lying immediately towards south of Hindustan Aeronautic Limited (HAL) airport, shows maximum population growth when compared to other area or wards of the city, which is in consonance to the computed entropy values for different cardinal zones. Ward level decadal population growth rate in BBMP area (2001-2011) as shown in Figure 7 also supports the same argument.

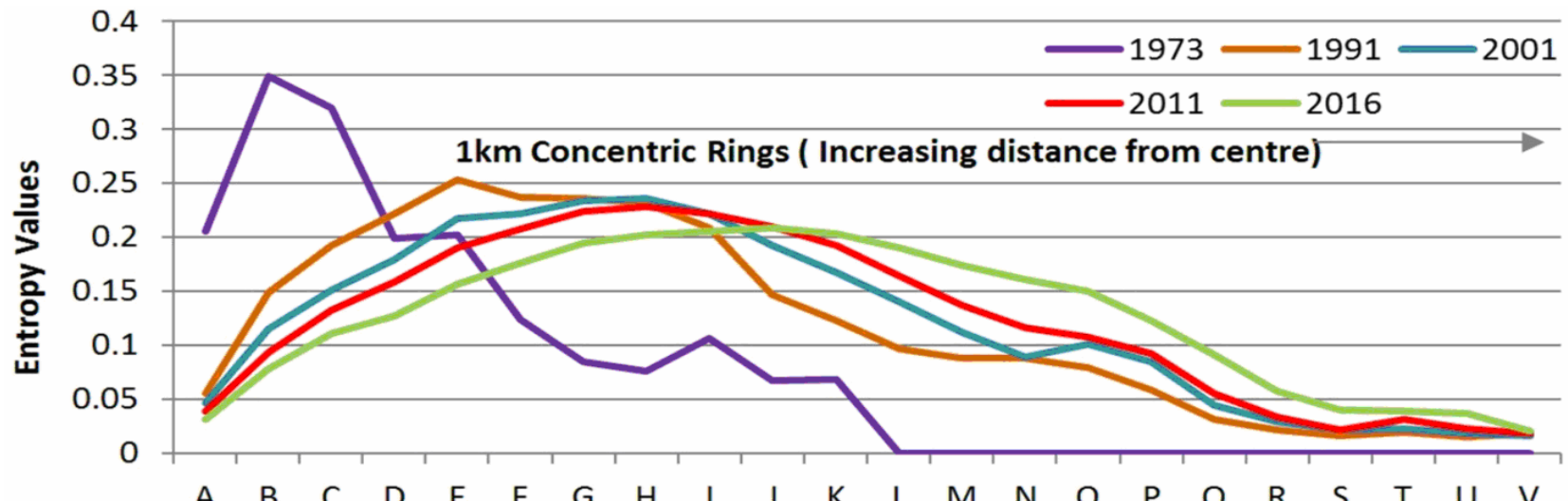

Fig. 6. Showing the distance from city core and entropy value in each ring of Bengaluru city.

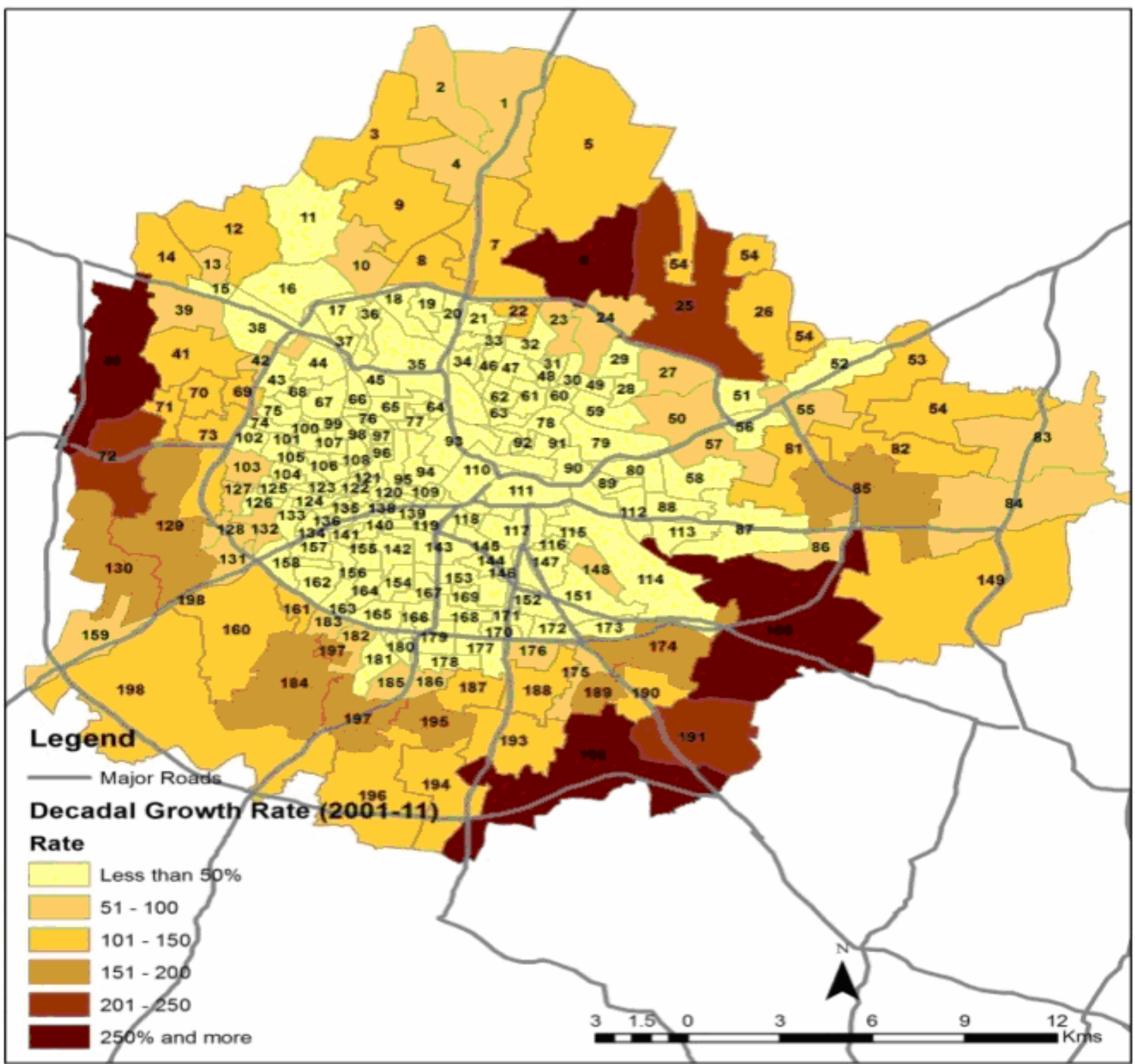

Fig. 7. Ward level decadal population growth rate in BBMP area (2001-2011). Source: Census of India (2001-2011) [26], [27]. 


\section{CONCLUSION}

Bengaluru has grown from the small village when a chieftain called Kempe Gowda established it in 1537 A.D. From an area of hardly 18 sq km, Bengaluru raced past the conical towers erected by Gowda II and in 2016 it encompassed a total of $737 \mathrm{sq} \mathrm{km}$ and is still expanding. Bengaluru's new found prosperity has spawned a building boom. To meet the shortage of housing and the demand for commercial establishments at the south-east zone of Bengaluru, multi-storied building construction has become the major choice. A transition phase of urban centre shifting is noticed at southeast zone (HAL, International Tech park, Whitefield, Prestige Tech Park, and Kadubeesanahalli etc.), where green cover and water bodies disappeared at a rapid rate and transformed into built-up land mostly with buildings of five to fifteen floors. The permitted Floor Space Index (FSI) in the central areas is 1.25 but 2.5 at peripheral areas. The population density from city core was observed to be shifting around south-east periphery due to IT establishments and cheaper land prices. The entropy values indicated an increase from 1.8 in 1973 to 2.77 in 2016, signifying dispersion of the settlement in the last four decades particularly more in NE and SE zones (2.79 and 2.76 respectively) when compared to NW and SW zones (2.49 and 2.47 respectively). This needs suitable and timely action to ensure commensurate provision of infrastructure. The study demonstrates the role of remote sensing and Geographic Information System technology in combination with Shannon's entropy technique for performing a spatial analysis and measuring urban sprawl which may be useful in informing future urban plans and urbanization policies of any city. The model presented in this study can be useful in identifying, measuring and predicting the urban development trends. From the analysis, it is evident that the population has exponentially increased in Bengaluru, but the built-up area to cater the growing population reduced in the recent years, indicating overall compact growth in parts of the city. With emerging issues of increasing trip length, environmental issues and increasing infrastructure costs, Shannon's entropy integrated with other analytical tools may provide a powerful methodology to identify the spatial pattern of the urban growth and formulate suitable development policies for sustainable development.

\section{REFERENCES}

[1] Yeh, A. G., Li, X. (2001), Measurement and monitoring of urban sprawl in a rapidly growing region using entropy, Photogrammetric Engineering and Remote Sensing, vol. 67, no 1, pp. 83-90.
[2] Weng, Q. (2001), A remote sensing - GIS evaluation of Urban expansion and its impact on surface temperature in the Zhujiang Delta, China, International Journal of Remote Sensing, vol. 22, no. 10, pp. 1999-2014.

[3] Census of India (2011a), Provisional Population Totals paper 2 of 2011 India Series 1, India.

[4] United Nations (2014), World Urbanization Prospects, Available at: http://esa.un.org/undp/wup/ Highlights/WUP2014-Highlights.pdf. Last accessed: June, 10, 2017.

[5] Ramachandra, T. V. (2016), Bengaluru will be a 'a dead city in 5 years. Available at: http://wgbis.ces.iisc.ernet.in/energy/wetlandandnews/ news-2016/canindia-bengaluru-will-be-dead-in-fiveyears-060516.pdf. Last accessed: June, 21, 2017.

[6] Champion, T. (2001), Urbanization, Suburbanization Counter - Urbanization and ReUrbanization. In: R. Padison [editor] Handbook of Urban Studies, Sage Publication, London, pp. 143-160.

[7] Lie, C. L., Zhang, H. (2009), On the Characteristics of Housing Spatial Structure and Location Selection of Residential Communities: A case of Wuhan City, Journal of Geography and Geology, vol. 1, no 1, pp. 7-19.

[8] Glaeser, E. L., Kahn, M. E. (2004), Sprawl and Urban Growth. In: Handbook of Regional and Urban Economics, J. Vernon Henderson and Jacques-François Thisse [editors] Cities and Geography. Elsevier, Amsterdam pp. 2481-2527.

[9] Sudhira, H. S., Ramachandra, T. V., Jagadish, K. S. (2004), Urban Sprawl: Metrics, Dynamics and Modelling using GIS. International Journal of Applied Earth Observation and Geoinformatics, vol. 5, no. 1, pp. 29-39.

[10] Glaeser, E. L., Gyourko, J., Saks, R. E. (2006), Urban Growth and Housing Supply, Journal of Economic Geography, vol. 6, no. 1, pp. 71-89.

[11] Taubenbock, H., Wegmann, M., Roth, A., Mehl , H., Dech, S. (2009), Urbanization in India Spatio temporal analysis using remote sensing data. Computers, Environment and Urban System, vol. 33, no. 3, pp. 179-188.

[12] Ochs, W. (1975), A unique characterization of the generalized Boltzmann - Gibbs - Shannon Entropy. Physics Letters A, vol. 54, no. 3, 189-19o.

[13] Shannon, C. (2001), The mathematical theory of communication. ACM SIGMOBILE mobile computing and communications review, vol. 5, no. 1, pp. 3-55.

[14] Ishizaki, R., Inoue, M. (2013), Time series analysis of foreign exchange rates using time dependent pattern entropy, Physics A: Statistical Mechanics and its Applications, vol. 392, no. 16, pp. 3344-3350.

[15] Wu, S., Wu, C., Lin, S. (2014), Analysis of complex time series using refined composite multi- 
scale entropy, Physics Letters A, vol. 378, issue 20, pp. 1369-1374.

[16] Frank, O., Shafie (2016), Multivariate Entropy Analysis of Network Data. Bulletin of Sociological Methodology, vol. 129, issue 1, pp. 45-63.

[17] Batty, M. (1974), Spatial Entropy, Geographical Analysis, vol. 6,(1)pp 1-31.

[18] Shekhar, S. (2004), Urban Sprawl Assessment: Entropy Approach. Available at: http://www.archidev. org. Last accessed: June 15, 2017.

[19] Alabi, M. O. (2009), Urban Sprawl, Pattern and Measurement in Lokoja, Nigeria, Theoretical and Empirical Researches in Urban Management.

[20] Mohammady, S., Delavar, M. R. (2015), Urban Sprawl Monitoring. Modern Applied Sciences, vol. 9, no 8, pp. 1-12.

[21] Jat, M. K., Garg, P. K., Khare, D. (2007), Monitoring and modelling urban sprawl using remote sensing and GIS techniques, International Journal Application of Earth Observation and Geoinformation, vol. 10, Issue 1, pp. 26-43.

[22] Kumar, J. A., Pathan, S. K., Bhanderi, R. J. (2007), Spatio-temporal analysis for monitoring urban growth - a case study of Indore city, Journal of the Indian Society of Remote Sensing, vol. 35, Issue 1, pp. 11-20.

[23] Census of India (1971), Primary Census Abstract, UA/Towns., Census of India, New Delhi.

[24] Census of India (1981), Primary Census Abstract, UA/Towns., Census of India, New Delhi.

[25] Census of India (1991), Primary Census Abstract, UA/Towns., Census of India, New Delhi.
[26] Census of India (2001), Primary Census Abstract, UA/Towns., Census of India, New Delhi.

[27] Census of India (2011b), Primary Census Abstract, UA/Towns., Census of India, New Delhi.

[28] BDA (2015), Bangalore Master Plan-2015, Bangalore Development Authority, Karnataka.

[29] BBMP (2015), Revised City Development Plan for Bangalore

[30] Schneider, A., Woodcock, C. E. (2008), Compact, Dispersed, Fragmented, Extensive? A Comparison of Urban Growth in Twenty-five Global Cities using Remotely Sensed Data, Pattern Metrics and Census Information, Urban Studies, vol. 45, issue 3, pp. 659-692.

[31] Shaw, A., Satish, M. K. (2006), Metropolitan restructuring in post Liberalized India: Separating the global and the local, Cities, vol. 24, issue 2, pp. 148-163. [32] Census of India (1901-2001), Primary Census Abstract, Census of India.

[33] Anderson, J. E., Hardy, J. R., Winter, R. (1976), A landuse and land cover classification system for use with remote sensor data, Professional Paper 964.

[34] Ranpise, R. S., Kadam, A. K., Gaikwad, S. W., Meshram, D. C. (2016), Appraising SpatioTemporal Shifting of Urban Growth Centre of PimpriChinchwad Industrialized City, India using Shannon Entropy Method, Current urban Studies, vol. 4, no. 3, pp. 343-355. 